\title{
Icelandic Tax News 2013
}

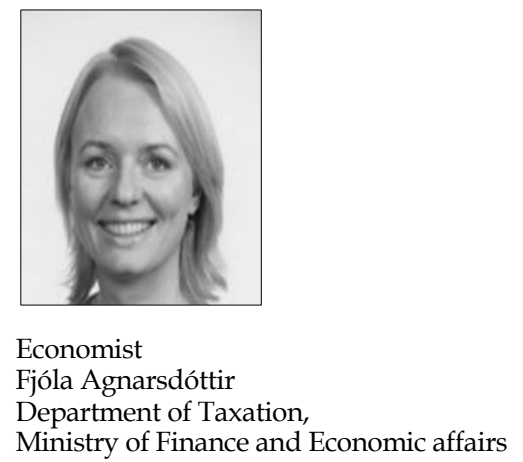

This article reviews the most significant changes made to the Icelandic tax system in 2013. Many of the changes were implemented on the basis of fiscal objectives laid out in the 2014 state budget, while others were motivated by the social and political agenda of Iceland's ruling government in 2013. A new Government was formed in May 2013. The Government's goal according to its manifesto is to analyse the tax system in light of the amendments made for the past few years with the aim to simplify the tax system, broaden the tax base and minimise tax avoidance.

\section{Personal income tax}

From 2010 the personal income tax in Iceland has been levied in three brackets. In 2013, the tax rates levied by the central government were unchanged from 2012 whereas the cut-off amounts between brackets were slightly increased. A rate of $22.9 \%$ applied to income up to ISK 241475 per month (230 000 in 2012), a rate of $25.8 \%$ to income between $241476-739509$ (230 001-704 367 in 2012) and a rate of 31.8\% to income over 739509 per month (704 367 in 2012). The personal tax credit in 2013 was ISK 48485 per month, up from ISK 46532 in 2012. In 2013, the average income tax rate levied by local governments was $14.42 \%$, the same rate as in 2012. In late 2013 Althingi made amendments to act no. 90/2003 which entered into force on 1 January 2014 were the middle bracket was lowered to $25.3 \%$ while the highest bracket was unchanged at $31.8 \%$. At the same time the lower cut-off amount for the middle bracket was increased by $20 \%$. 


\section{Corporate income tax and employers' social security contributions}

Corporate income tax for the assessment year 2013 (operations 2012) was $20 \%$ and it will remain unchanged for the assessment year 2014 (operations 2013). In 2013, the social security charge on total wages was lowered to $7.69 \%$ from $7.79 \%$ in 2012 to reflect more favourable labour market developments. Financial and insurance companies are subject to an additional wage and profits tax referred to as a financial activities tax and will be described further in the following section.

\section{Financial sector taxation}

In recent years the Government has implemented new taxes to the financial sector. One is the bank tax passed by Althingi in 2010 becoming effective from 1st of January 2011. The second one, the financial activity tax (FAT), entered into force on 1st of January 2012. These new taxes were based on the International Monetary Fund's (IMF) recommendations.

The bank tax was first levied on commercial banks, savings banks, credit institutions and other institutions which had an operating license to receive deposits. The tax base is year-end total outstanding debt and the tax rate was $0.041 \%$ until end-year 2013. In late 2013, amendments to the bank tax were passed where the tax rate was raised to $0.376 \%$ and the tax base widened by abolishing the exemption of financial institutions in winding-up process. A tax free limit was also introduced amounting to year-end total outstanding debt over ISK 50 billion. The FAT, which is levied on financial institutions and insurance companies (excluding pension funds), has two components: (i) a levy on total remuneration paid to employees and (ii) a special income tax on institutions' corporate income tax base in excess of ISK 1 billion. ${ }^{1}$ In 2013 , the rate of the wage tax was $6.75 \%$ but it has been was lowered to $5.5 \%$ in 2014. to counterbalance the increase in the bank tax. The rate of the special income tax is $6 \%$ and has been unchanged since implementation.

1 This second component was introduced via amendments to the act on income tax. 


\section{Value added tax}

The general value added tax rate in Iceland is $25.5 \%$ but some product categories and services are subject to a lower rate of 7\%. In late 2013, an amendment was made to the value added tax lowering the VAT rate on disposable diapers from $25.5 \%$ to $7 \%$.

\section{Stamp duty}

A new and revised legislation on stamp duty entered into force on 1 January 2014. According to the new legislation, a stamp duty is only levied on documents relating to the transfer of ownership of property and ships over 5 gross tonnage registered in the country. Few documents are, however, specifically exempt from the stamp duty, the main ones being related to transfer of ownership due to inheritance and estate settlements. The main change of the new legislation from the old one is that the stamp duty on loan agreements was abolished.

\section{Exit taxation of cross border mergers.}

Provisions were added to the Income Tax Act, which entered into force 1 January 2014, regarding tax treatment of cross-border mergers of limited liability companies to comply with the judgment of the EFTA Court, in Case E-14/13, dated 2 December 2013. Prior to the amendment the general rule was that companies which merged crossborder within the EEA were required to pay tax on all capital gains relating to assets and shares when they left Iceland, even though the gains had not been realized. Icelandic companies that merged with other companies within Iceland were under no such obligation.

According to the new provisions, unrealized capital gains originated from a limited liability company exiting Iceland will be taxed when merging cross-border with a limited liability company in another Member State of the European Economic Area, EFTA state or the Faroe Islands, but a tax deferral for up to five years will be granted upon request. Interest must be paid during this deferral period. The amount of the tax, the collection of which is deferred, is subject to appropriate guarantees when the deferred tax amount is more than 50 million ISK. 


\section{Transfer Pricing}

New statutory rules on transfer pricing entered into force at the beginning of $2014^{2}$ but until that time no specific rules on transfer pricing were applicable in Iceland apart from the general anti avoidance principle in the Icelandic Income Tax Act. ${ }^{3}$

The new transfer pricing rules in the Income Tax Act apply both to domestic and international transactions. There is an explicit reference to the OECD Transfer Pricing Guidelines for Multinational Enterprises and Tax Administrations and the intention is to take notice of the OECD work in this field when applying the Icelandic rules. Not all parties are subject to a documentation obligation according to the rules, since the obligation applies only to companies/entities where the annual turnover exceeds 1 billion ISK or if the total assets are above that amount.

\section{Tax treaties}

A revised tax treaty with the United Kingdom was signed in December 2013 which hopefully will become effective from 1 January 2015. A protocol to the treaty with Poland was ratified in 2013 which became effective on 1 January 2014.

Three tax information exchange agreements came into force in 2013; Seychelles, Mauritius, and Panama. Two new TIEAs were signed in 2013 with Botswana and Niue. These agreements are the results of the Nordic Steering Group negotiations with low tax jurisdictions. Iceland has signed 42 TIEAs by the end of year 2013 and 30 of those have already entered into force.

2 Article 57 para. 3-6 of the Income Tax Act No 90/2003.

3 Article 57 para. 2-3 of the Income Tax Act No 90/2003. 